\title{
Correction to: Investigating diagnosis, treatment, and burden of disease in patients with ankylosing spondylitis in Central Eastern Europe and the United States: a real-world study
}

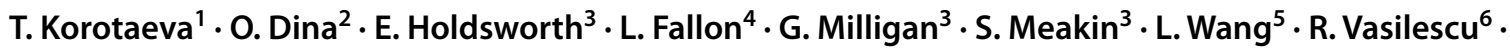 \\ J. C. Cappelleri ${ }^{5} \cdot$ A. Deodhar ${ }^{7}$
}

Published online: 27 January 2022

(c) The Author(s) 2022

\section{Correction to: Clinical Rheumatology (2021) 40:4915-4926 https://doi.org/10.1007/s10067-021-05864-8}

The article "Investigating diagnosis, treatment, and burden of disease in patients with ankylosing spondylitis in Central Eastern Europe and the United States: a real-world study", written by T. Korotaeva, O. Dina, E. Holdsworth, L. Fallon, G. Milligan, S. Meakin, L. Wang, R. Vasilescu, J. C. Cappelleri and A. Deodhar, was originally published Online First without Open Access. After publication in volume 40, issue 12, page 4915-4926 the author decided to opt for Open Choice and to make the article an Open Access publication. Therefore, the copyright of the article has been changed to () The Author(s) 2022 and the article is forthwith distributed under the terms of the Creative Commons Attribution 4.0 International License, which permits use, sharing, adaptation, distribution and reproduction in any medium or format, as long as you give appropriate credit to the original author(s) and the source, provide a link to the Creative Commons licence, and indicate if changes were

The original article can be found online at https://doi.org/10.1007/ s10067-021-05864-8.

T. Korotaeva

tatianakorotaeva@gmail.com

1 Institute of Rheumatology V.A. Nasonova, 115522

Kashirskoe shosse 34-A, Moscow, Russia

2 Pfizer Inc, New York, NY, USA

3 Adelphi Real World, Bollington, UK

4 Pfizer Inc, Kirkland, QC, Canada

5 Pfizer Inc, Groton, CT, USA

6 Pfizer, Brussels, Belgium

7 Oregon Health \& Science University, Portland, OR, USA made. The images or other third party material in this article are included in the article's Creative Commons licence, unless indicated otherwise in a credit line to the material. If material is not included in the article's Creative Commons licence and your intended use is not permitted by statutory regulation or exceeds the permitted use, you will need to obtain permission directly from the copyright holder. To view a copy of this licence, visit http://creativecommons. org/licenses/by/4.0.

Open Access This article is licensed under a Creative Commons Attribution 4.0 International License, which permits use, sharing, adaptation, distribution and reproduction in any medium or format, as long as you give appropriate credit to the original author(s) and the source, provide a link to the Creative Commons licence, and indicate if changes were made. The images or other third party material in this article are included in the article's Creative Commons licence, unless indicated otherwise in a credit line to the material. If material is not included in the article's Creative Commons licence and your intended use is not permitted by statutory regulation or exceeds the permitted use, you will need to obtain permission directly from the copyright holder. To view a copy of this licence, visit http://creativecommons.org/licenses/by/4.0/.

Publisher's Note Springer Nature remains neutral with regard to jurisdictional claims in published maps and institutional affiliations. 